J. Product. \& Dev., 18(3):437-445(2013)

\title{
TOMATO YELLOW LEAF CURL VIRUS: EFFICIENCY OF ACQUISITION, RETENTION AND TRANSMISSION BY BEMISIA TABACI (GENNADIUS), IN LIBYA
}

\author{
H. El-Sharkawy", Mersal, $\boldsymbol{R}^{* *}$ and El Muttardy, F.* $^{* *}$ \\ 1-Department of Plant Production, Faculty of Technology and \\ Development, Zagazig University, Egypt. \\ 2- Department of Zoology, Faculty of Science, Benghazi University, Libya.
}

\section{ABSTRACT}

The sweet potato whitefly ,Bemisia tabaci (Gennadius)is considered as vector for numerous plant viruses, including tomato yellow leaf curl virus(TYLCV). Experiments confirmed the ability of Bemisia tabaci adult to acquire and transmit the virus to the tomato plantations in Libya. The acquisition threshold feeding period ranged 30-40 min from infected tomato plant to healthy celery and from infected celery plant to healthy one $25-40 \mathrm{~min}$. Moreover, retransmission from infected celery plants to healthy tomato plants 30 - $45 \mathrm{~min}$. On the other hand inoculation threshold feeding period ranged from5-10min.The incubation period in white fly Bemisia tabaci was21-24 hours but in tomato plants ranged from 1012 days and in celery plants 7-9 days. The Retention period of Tomato Yellow Leaf Curl Virus (T Y LC V) in whitefly Bemisia tabaci was 8- 11 days.

Results of this study will help to understand the epidemiology of $(T Y L C V)$ in tomato plantations. Also the tomato plants and virus vector relationships of Libyan isolate are reported for the first time.

Conclusively, from these results, it could be concluded that transmission experiments proved that tomato yellow leaf curl geminivirus is transmitted by Bemisia tabaci in a persistent manner.

Key words: Bemisia tabaci, tomato yellow, leaf curl, begomovirus, tomato virus disease.

\section{INTRODUCTION:}

Bemisia tabaci is a plant sap-sucking insect belong to the family Aleyrodidae in the superfamily Aleyrodoidea (whiteflies). It is broadly polyphagous, feeding on an estimated 600 plant species. Since the early 1980 s it has caused escalating problems to both field and protected agricultural crops and wide variety of vegetable, ornamental and other crops worldwide in many regions wit tropical, subtropical, aired and 
Mediterranean climate.(Jones, 2003 and Ma et al., 2007). Heavy infestations of $B$. tabaci may reduce host vigour and growth, cause chlorosis and uneven ripening, and induce physiological disorders. The larvae excrete honeydew on which sooty moulds grow, reducing the photosynthetic capabilities of the plant, resulting in defoliation and stunting. Bemisia tabaci is also a vector of 111 plant viruses in the genera Begomovirus (Geminiviridae), Crinivirus (Closteroviridae) and Carlavirus or pomovirus (Potyviridae) (Jones, 2003). Begomoviruses are the most numerous of the B. tabaci transmitted viruses and can cause crop yield losses of between 20\% and 100\% (Brown \& Bird, 1992 and Sohani et al., 2007). Tomato yellow leaf curl begomovirus (TYLCV), Genus: Begomovirus, Family: Geminiviridae, is one of the major factor limiting tomato(Lycopersicon esculentum Mill)., production in tropical and subtropical regions in the world and in many Mediterranean and Middle Eastern countries (Jones et al., 1993; Markham et al., 1994; Czosnek and Latterote, 1997). The virus was first observed in eastern Mediterranean since 1966 (Lapidot and Friedman, 2002).

The incidence of symptomatic plants was up to $100 \%$ with heavy losses in tomato yield up to $80 \%$ especially when plants are infected in early stage of growth (Cohen and Antignus, 1994; Lourou et al., 1996; Momol et al., 1999).

Symptoms induced by TYLCV on tomato plants include reduction in leaf size, leaf curling upward, severe stunting and distortion associated with interveinal chlorosis, observed mainly on the upper portion of plants (Martinez-Culebras et al., 2001; Salati et al., 2002). When infection occurs at early stage of growth, the plant exhibited severe stunting, dropping of flowers and stops producing marketable fruits. On the other hand, the epidemiology information of this disease is still lacking in Libya.

Therefore, the scope of the present study was to contribute towards a better knowledge of virus-vector relationship.

\section{MATERIALS AND METHODS}

\section{Source of the virus and its identification:}

Tomato plant samples taken from tomato plantation in green house at EL-Hawary region, Benghazi, Libya, during 2012 showing typical symptoms of TYLCV were selected for virus isolation and identification. This symptoms showed reduced internodes, giving the plant a stunted appearance. The new leaves also greatly reduce in size and wrinkled, as well as yellowed between the veins and with margins that curl upward, giving them a cup like appearance with heavy infestation with Bemisia 
tabaci (Gennadius) was observed .Infected tomato plants were transplanted to plastic pots $(30 \mathrm{~cm}$-diamter) and maintained as stock plants in green house at department of botany, Faculty of Benghazi ,Libya. On the other hand, some infected tomato plant samples send to department of virology of plant pathology Institute Agriculture Research Center (ARC), Cairo, Egypt to isolate the virus. The virus isolated from infected samples.

\section{Rearing whitefly Bemisia tabaci (Gennadius):}

Adults of whitefly were obtained from healthy tomato plants and reared on sweet potato according to the technique modified by Sherif (1978) to be free from any contaminating pathogens before using in tests.

\section{Test plants:}

Two types of test plants were used in experiments: The first one was healthy tomato plants seedling at the first true leaf as principle host of the virus. The second was celery (Apium graveolens) plants as indicator for plant viruses.

\section{Virus transmission}

To insure, the maintain of the whitefly on the test plants through the acquisition access period (AAP) or inoculation access period (IAP), small plastic boxes were constructed for continuous stay of whitefly on the test plants according to description by El-Sharkawy (1989).

The used adults of whitefly were classified into different groups according to the length of feeding period. To confirm the ability and the efficiency of whitefly as an economic vector virus of TYLCV, subsequent transmissions by whitefly were carried out from artificially infected celery plants, showing characteristic symptoms to healthy ones and from celery to tomato plants as the principle host plant. In case of both acquisition and inoculation feeding using 10 insects/plants were used the time feeding ranged from 5-60 min. The plants were kept under growth chamber condition at $24-28 \mathrm{C}^{\circ}, 12 \mathrm{~h}$ light and $70-75 \% \mathrm{RH}$ for assessment of symptom appearance.

The percentages of virus infection were calculated from test plants showing TYLCV symptoms up 25 days.

\section{RESULTS}

1.Tranasmission of Tomato yellow mosaic virus (TYMV) by whitefly: 1.1. Effect of length of acquisition access period on the efficiency of (TYMV) Transmission:

The results of primary experiments showed that the efficiency of TYLCV transmission by white fly increased gradually as acquisition 
access period (AAP) increased from infected tomato plant to healthy celery plant and from infected celery plant to healthy plant also and from infected celery to healthy tomato plants (Table 1). The obtained results showed that efficiency of TYLCV transmission by white fly Bemisia tabaci ranged from $40-100 \%$, also the results obtained showed white fly in most cases can acquire viruses after, reaching the adult stage . It was determined that $B$. tabaci required the following minimum acquisition feeding periods from infected tomato plant to healthy celery $30-40 \mathrm{~min}$, from infected celery plant to healthy one 25-40 min. Also retransmission from infected celery plants to healthy tomato plants occurred in $30-45 \mathrm{~min}$, for Tomato yellow leaf curl virus (TYLCV).

Symptoms on tomato seedling appeared within 10-12 day after transmission of virus showing leaf curling, leaf reduction, general stunting with or without yellowing.

Table 1: Transmission ability of Tomato Yellow Mosaic Virus (TYMV) by whitefly B. tabaci in tomato and celery plants.

\begin{tabular}{|c|c|c|c|}
\hline \multirow{2}{*}{$\begin{array}{c}\text { Acquisition } \\
\text { access period } \\
\text { on infected } \\
\text { plant (Min) }\end{array}$} & $\begin{array}{c}\text { From infected } \\
\text { tomato plant } \\
\text { to healthy } \\
\text { celery }\end{array}$ & $\begin{array}{c}\text { From infected } \\
\text { celery plant } \\
\text { to healthy } \\
\text { one }\end{array}$ & $\begin{array}{c}\text { Retransmission } \\
\text { from infected } \\
\text { celery plant to } \\
\text { healthy Tomato } \\
\text { plant }\end{array}$ \\
\hline 0 & $00 \%$ & $00 \%$ & $00 \%$ \\
\hline 5 & $00 \%$ & $00 \%$ & $00 \%$ \\
\hline 10 & $00 \%$ & $00 \%$ & $00 \%$ \\
\hline 15 & $00 \%$ & $00 \%$ & $00 \%$ \\
\hline 20 & $00 \%$ & $00 \%$ & $00 \%$ \\
\hline 25 & $00 \%$ & $40 \%$ & $00 \%$ \\
\hline 30 & $40 \%$ & $40 \%$ & $40 \%$ \\
\hline 35 & $40 \%$ & $40 \%$ & $40 \%$ \\
\hline 40 & $60 \%$ & $60 \%$ & $40 \%$ \\
\hline 45 & $60 \%$ & $60 \%$ & $60 \%$ \\
\hline 50 & $80 \%$ & $100 \%$ & $80 \%$ \\
\hline 55 & $100 \%$ & $100 \%$ & $80 \%$ \\
\hline 60 & $100 \%$ & $100 \%$ & $100 \%$ \\
\hline
\end{tabular}




\section{2: Incubation period of TYMV in white fly Bemisia tabaci :}

The incubation period of TYMV in whitefly Bemisia tabaci ranged between 21-24 hours.

\subsection{Effect of inoculation access period (IAP) on transmission} TYMV by white fly Bemisia tabaci:

Inoculation access periods of $(5-10 \mathrm{~min})$, proved insufficient for successful inoculation of TYLCV at 15 min proportion of infected plants was $40 \%$ and the highest proportion of infected plants was $100 \%$ (Table 2). Symptoms on celery plants appeared within 7-9 days after their inoculation with the pathogen by the whitefly Bemisia tabaci. The symptoms on infected celery seedlings showing reduction in size of leaves crumpled and turn yellow along the edges and between veins.

Table 2: Effect of inoculation access period (IAP) on transmission of TYMV by whitefly Bemisia tabaci from infected tomato to healthy celery seedlings.

\begin{tabular}{|c|c|}
\hline $\begin{array}{c}\text { Inoculation access periods } \\
\text { on healthy celery seedlings } \\
\text { (min) }\end{array}$ & $\begin{array}{l}\text { Efficiency of virus retransmission } \\
\text { from infected tomato to healthy } \\
\text { celery seedlings by Bemisia tabaci }\end{array}$ \\
\hline 0 & $00 \%$ \\
\hline 5 & $00 \%$ \\
\hline 10 & $00 \%$ \\
\hline 15 & $40 \%$ \\
\hline 20 & $40 \%$ \\
\hline 25 & $60 \%$ \\
\hline 30 & $60 \%$ \\
\hline 35 & $60 \%$ \\
\hline 40 & $80 \%$ \\
\hline 45 & $80 \%$ \\
\hline 50 & $100 \%$ \\
\hline 55 & $100 \%$ \\
\hline 60 & $100 \%$ \\
\hline & \\
\hline & \\
\hline & \\
\hline
\end{tabular}

\subsection{Retention period of viruses in whitefly Bemisia tabaci :}

The retention period of tomato yellow mosaic virus (TYMV) in whitefly Bemisia tabaci was 8 -11 days. 


\section{DISCUSSION}

The whitefly Bemisia tabaci is an important natural vector for many plant viruses including TYLCV. Adults and crawlers $\left(1^{\text {st }}\right.$ instar) are the only stages where the insect is able to acquire and transmit TYLCV .Also single insects are able to acquire TYLCV and transmit it to tomato plant (Mehta et al., 1994). Minimum effective acquisition access and inoculation access periods are approximately 10-20 min. The rate of transmission increases with longer acquisition and inoculation access periods. A minimum of $8 \mathrm{~h}$ (latent period) from the time acquisition started is required for $B$. tabaci to be able to infect tomato test plants. In one insect / one plant inoculation test, females B. tabaci are more efficient $(\sim 95 \%)$ than male insects $(\sim 25 \%)$. Viral DNA can be detected in single insects by PCR after $5 \mathrm{~min}$ of access feeding, and in tomato plants as early as $5 \mathrm{~min}$ after inoculation feeding (Atzmon et al., 1998 and Al-ani et al., 2011).

The present study of insects transmission experiments recorded the acquisition threshold feeding period ranged from infected tomato plant to healthy celery 30-40 min, from infected celery plant to healthy one 25$40 \mathrm{~min}$, and retransmission from infected celery plants to healthy tomato plants 30-45 min, inoculation threshold feeding period ranged from 5$10 \mathrm{~min}$, incubation period in tomato plants ranged from 10-12days and in celery plants 8-10 days also the retention period of tomato yellow leaf curl virus (TYLCV) in whitefly Bemisia tabaci was 8-11 days.

These results obtained in this study were agreed with finding of some others (Hegab, 1988 and Mansour \& Al-Mousa, 1992) and were disagreed with other (Ajan et al., 2006) due to the Libyan isolate of TYLCV which may differ slightly in the biology and virus -vector relationship from those isolates described earlier, the number of whitefly used a similar conclusion was draw by (Kasrawi et al., 1988). The minimal latent period reported was $21 \mathrm{~h}$ (Cohen and Nitzany, 1966.) but was $24 \mathrm{~h}$ for the closely related TYLCV strain from Egypt (Mehta et al., 1994) and 17h for the more distant virus from Sardinia (Caciaglie et al., 1995).

Moreover, the rate of transmission increased with increasing population density of the vector ( Ajan et al., 2006). Geminivirus particles are thought to be ingested along with phloem sap of infected plants through the stylets and enter the esophagus and the filter chamber.

The virus particles are subsequently transported through the gut wall into the hemocoel and from there they reach the salivary glands. The virus is trans located into the salivary duct and is finally excreted with the saliva during feeding. The time it takes for a geminivirus to complete this path is reflected in the minimal period of time that elapses from beginning 
of feeding on infected plants to transmission to test plants(latent period). This wide range latent period of values may reflect the efficiency with which a given virus establishes a systemic infection in a plant rather than differences in the velocity of translocation in the insect vector (Murad et al., 2001).

Conclusively, from these results, it could be concluded that transmission experiments proved that tomato yellow leaf curl geminivirus is transmitted by Bemisia tabaci in a persistent manner.

\section{REFERENCES}

Ajan, M. A.; Ghanem, A. M. and Abdulsalam, K. S.(2006): Tomato yellow leaf curl virus (TYLCV) in Saudi Arabia, identification, partial characterization and virus-vector relationship. Arab. J. Biotech., 10 (1):179-192.

Al-ani, A. R.; Adhab, A. M.; Hamad, H. A. and Diwan, H. N. (2011): Tomato yellow leaf curl virus (TYLCV), identification, virus vector relationship, strains characterization and a suggestion for its control with plant extracts in Iraq. African Journal of Agriculture Research, 6 (22):5149-5155.

Atzmon, G.; Van Hoss, H. and Czosnek, H.(1998): PCR-amplification of tomato yellow leaf curl virus (TYLCV) from squashes of plants and insect vectors: Application to the study of TYLCV acquisition and transmission. Eur. J. Plant Pathol., 104:189-194.

Brown, J. K. and Bird, J. (1992): Whitefly-transmitted Gemini viruses and associated disorders in the Americas and the Caribbean Basin. Plant Disease, 76: 220-225.

Caciagli, P.; Bosco, D. and Al-Bitar, L.(1995): Relationships of the Sardinian isolate of tomato yellow leaf curl geminivirus with its whitefly vector Bemisia tabaci Gen. Eur. J. Plant Pathol., 101:163-170.

Cohen, S. and Antignus, Y. (1994): Tomato yellow leaf curl virus, a whitefly borne geminivirus of tomatoes. In: Advances in Disease Vector Research, Springer - Verlag. N.Y., 10: 259-288.

Cohen, S. and Nitzany, $\boldsymbol{F}$. E. (1966):Transmission and host range of the tomato yellow leaf curl virus. Phytopathology, 56:1127-1131.

Czosnek, H. and Laterrot, H. (1997): A world-wide survey of Tomato yellow leaf curl viruses. Arch. Virol., 142: 1391-1406.

El- Sharkawy, H. M. (1989): Studies on some plant pathogenic vectors in vegetable plantations at Sharkia Governorate. M. Sc. Faculty of Agriculture, Zagazig University, Egypt. 
Hegab, M. A. (1988): Whitefly Bemisia tabaci (Genn.) as vector of plant pathogenic viruses infesting tomato plants in Egypt. Zagazig Journal of Agriculture Research, 15 (2):755-771.

Jones, D. (2003): Plant viruses transmitted by whiteflies. European Journal of Plant Pathology, 109: 197-221.

Jones, J.B.; Stall, R. E., and Zitter, T. A. (1993): Compendium of Tomato Disease. The American Phytopathological Society Press. St. Paul, MN, 40-41.

Kasrawi, M. A.; Sowan, M. A. A. and Mansour, A. A. (1988):Sources of resistance to tomato yellow leaf curl virus (TYLCV) Lycopersicum sp. Euphtico, 37: 61-64.

Lapidot, M. and Friedman, M. (2002): Breeding for resistance to whitefly transmitted geminiviruses. Ann. Appl. Biol., 140: 109-127.

Lourou, D.; Noris E.; Veratti, F. and Accotto, G.P. (1996): First report of tomato yellow leaf curl virus in Portugal. Plant Diseases, pp. 80-1079.

Ma, D.; Gorman, K.; Devine, G.; Luo Wa and Denholm, I. ( 2007): The biotype and insecticide resistance status of whiteflies, Bemisia tabaci (Hemiptera: Aleyrodidae), invading cropping systems in Xinjiang Uygur Autonomous Region, Northwestern China. Crop Protection, 26: 612-617

Mansour, A. and AL-Musa, A. (1992): Tomato yellow leaf curl virus, host range and virus-vector relationships. Plant Pathology, (41):122-125.

Markham, P.G.; Bedford, I. D.; Liu, S. and Pinner, M.S. (1994): The transmission of geminiviruses by Bemisia tabaci. Pestic. Sci., 42: 123-128.

Martinez-Culebras, P.V.; Font, I. and Jorda, C. (2001): A rapid PCR method to discriminate between Tomato yellow leaf curl virus isolates. Ann. Appl. Boil., 139: 251-257

Mehta, P.; Wyman, J. A.; Nakhla, M. K. and Maxwell, D. P. (1944): Transmission of tomato yellow leaf curl virus by Bemisia tabaci (Homoptera:Aelyrodidalae). J. Econom. Entomol., 87 (5): 1291-1297.

Momol, M.T.; Simon, W.; Sprenkel, K.; Olson, S. M.; Momol, E. A.; Polston, J. E. and, Hiebert, E. (1999): First report of Tomato yellow leaf curl virus in tomato in South Georgia. Plant Dis., 83(5): 487.

Murad, G.; Shai, M. and Henryk, C. (2001): Rate of Tomato yellow leaf curl virus Translocation in the Circulative Transmission Pathway of its Vector, the Whitefly Bemisia tabaci. Phytopathology, 91(2):189-196.

Salati, R.; Nahkla, M.K.; Rojas, M.R.; Guzman, P.; Jaquez, J.; Maxwell, D.P. and Gilbertson, R.L. (2002): Tomato yellow leaf curl virus in the Dominican Republic: Characterization of an infectious clone, virus monitoring in whiteflies, and identification of reservoir hosts. Phytopathology, 92:487-496. 
Sherif, R. M. (1978): Effect of certain pesticides on Bemisia tabaci Gennadius. M. Sc., Faculty of Agriculture, Zagazig University, Egypt.

Sohani, N. Z.; Shishehbor, P. and Kocheili, F.(2007):Thermal Effect on the Biology and Life Tables of Bemisia tabaci Gennadius (Homoptera: Aleyrodidae). Pakistan Journal of Biological Sciences, 10 (22):40574062.

\section{كفاءة اكتساب ونقل والاحتفاظ بفيروس مرض تجعد أوراق الطماطم

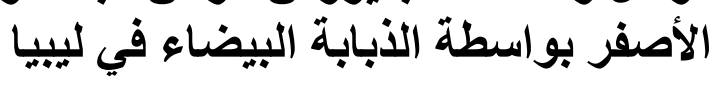

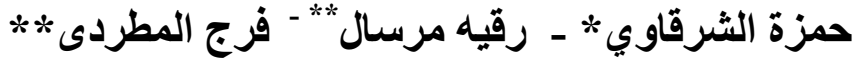

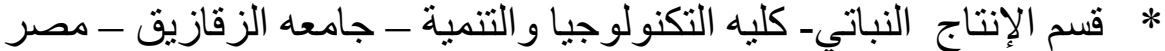

$$
\begin{aligned}
& \text { ** قسم الحيوان - كليه العلوم - جامعه بنغازي - ليبيا. }
\end{aligned}
$$

تعتبر الذبابه البيضاء من الناقلات للعديد من المسببات المرضية الفيروسية بما

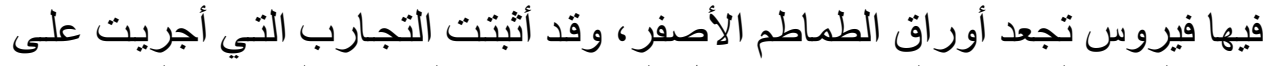

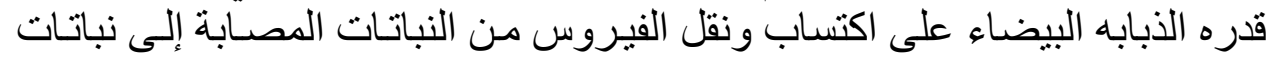

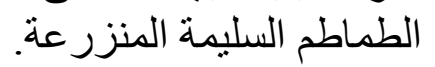

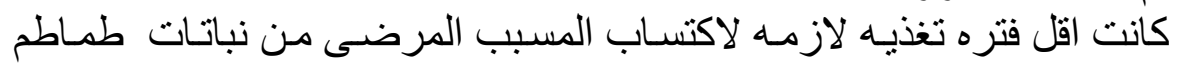

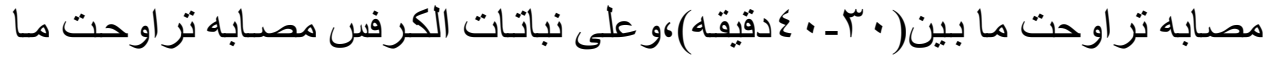

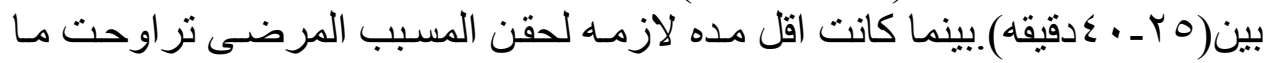
بين(0- • ا ( دقائق).

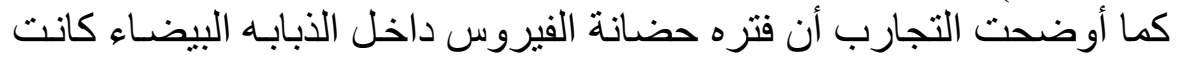

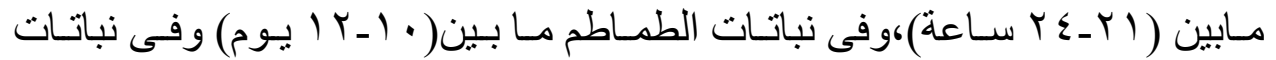

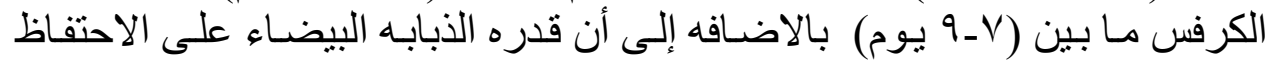

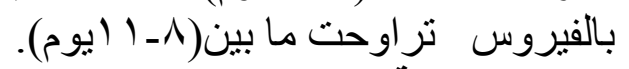

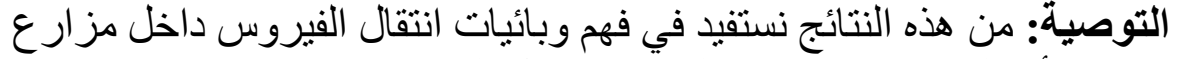

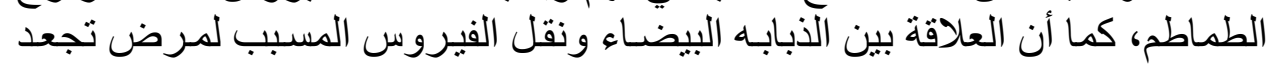
أوراق الطماطم الأصفر تسجل لأول بين الأبه للئه في ليبيا. 